\title{
How might normative and mimetic pressures improve local government service performance reporting?
}

\author{
Prae Keerasuntonpong, ${ }^{1}$ Carolyn Cordery ${ }^{2}$ \\ 1. Department of Accountancy, Chulalongkorn University, Bangkok, Thailand; \\ 2. School of Accounting and Commercial Law, Victoria University of \\ Wellington, Wellington, New Zealand. \\ *Corresponding author Prae Keerasuntonpong (prae@cbs.chula.ac.th)
}

Classification Codes: M48; H83; Q56

Key Words: Public Sector Accounting, Nonfinancial reporting; Environmental performance reporting

\begin{abstract}
Increasingly, public sector organisations are being encouraged or required to provide service performance information in addition to financial statements. Yet, reporting quality is often poor. This study investigates the disclosures of New Zealand local governments to analyse the effectiveness of the interventions to improve reporting. Drawing on contemporary institutional and legitimacy theories, we find that normative pressure in tandem with coercive pressure and threats to legitimacy, are influential in improving service performance reporting.
\end{abstract}




\section{Introduction}

Requirements for local government in New Zealand to report service performance information (in addition to traditional financial information) is due to the economic reforms carried out in the late 1980s. These reforms, commonly referred to as New Public Management (NPM) (Pallot, 1998), are similar to those undertaken in the United States, United Kingdom, Australia, and many other Western European countries (Olson, Guthrie, \& Humphery, 1998; Parker \& Gould, 1999). The three major principles of NPM were grounded on adoption of private-sector practices, pursuit of efficiency and effectiveness of service delivery, and development of explicit performance measures and targets (Glynn \& Perkins, 1997; Parker \& Gould, 1999).

Specification of expected performance was required to monitor the reforms' success, and for public sector entities to discharge accountability (Pallot, 1998). Performance measurement in the public sector (which had traditionally focused on inputs) shifted to an expectation of accountability for outputs (goods and services provided) and outcomes (overall changes effected) (Dixon, Kouzmin, \& Korac-Kakabadse, 1998; Parker \& Gould, 1999). New Zealand public sector entities led the world in reporting (output) service performance (Neale \& Pallot, 2001). By 1990, New Zealand public sector entities were required to report on their service performance plan and their subsequent service performance achievement in their annual reports (Local Government Act 1974; Public Finance Act 1989), and the standard setter developed a practice aid to assist such reporting (NZICA, 2007). More recently, recognising the need for these disclosures, other standard setters (for example, Governmental Accounting Standards Board (GASB) and International Public Sector Accounting 
Standard Board (IPSASB)), encourage public sector entities to report their service efforts and accomplishments (SEA) and service performance reporting, respectively (GASB2010; IPSASB2014). Indeed, the Australian and New Zealand accounting standards setters have revitalized their service performance reporting projects, with the efforts to issue new standards in this sphere. ${ }^{1}$

Despite this authoritative emphasis on service performance reporting, internationally shortcomings have been observed in the quality of public sector reporting. Indeed, prior researchers in public accounting in various jurisdictions have typically stated reporting (in particular, comparative performance measures) is underdeveloped (Boyne \& Law, 1991; Ellig, 2007; Foltin, 1999; Ho \& Ni, 2005; N. Hyndman \& Anderson, 1995; N. Hyndman \& Eden, 2002; Keerasuntonpong, 2011; Kloot, 2009; Lee, 2006, 2008; Lonti \& Gregory, 2007; Ryan, Stanley, \& Nelson, 2002; Smith \& Coy, 2000; Steccolini, 2004; Thompson, 1995; Tooley \& Guthrie, 2001). Even in New Zealand, the quality of public sector entities' service performance reporting has been criticized as being substandard, even years after it became a mandatory requirement (Office of the Auditor-General, 2008).

A number of factors contribute to the poor quality reporting of public sector entities; for example, lack of staff, staff expertise, financial resources, data availability, and (mis)perception of its importance (Boyne, Gould-Williams, Law, \& Richard, 2002; Boyne \& Law, 1991; Christiaens, 1999; Ingram, 1984; Lee, 2008). However, while these studies have considered organisational failings, they generally do not analyse longitudinal data, or the effects of interventions to improve the quality of service

\footnotetext{
See for example the July 2015 agenda papers of the Australian Accounting Standards Board http://www.aasb.gov.au/AASB-Board/Current-Board-papers.aspx and of the New Zealand Accounting Standards Board http://www.xrb.govt.nz/Site/Board_Meetings/NZASB_Board_Meetings.aspx.
} 
performance reporting. An assessment of the effectiveness of such interventions is important if such efforts are to be optimized. Accordingly, the scope of our study is to fill this lacuna by analysing the change in quality of service performance reporting over time as a result of specific interventions to improve it. We use contemporary institutional and legitimacy theories to add to the literature on influence service performance reporting.

Contemporary institutional theory ${ }^{2}$ advocates that external pressures, from coercive legislation, normative professionals and mimetic examples, can critically change organisational practice due to organisations' desire for legitimacy (DiMaggio and Powell, 1983, 1991; Greenwood and Hinings, 1996). In the public sector, Mulgan (1997) and Wimbush (2011) identify that external pressures, especially from scrutinizing or reviewing parliament officers (normative professionals such as parliamentary committees, the OAG and Ombudsman) play a major role in improving the public sector accountability (within extant coercive legislation). Although Parliament's power to enforce its criticisms has remained weak, public sector entities may face adverse publicity if they fail to address Parliament's criticisms (Mulgan, 1997), inferring that these entities will follow recommended practices to enhance their legitimacy. Imitation (of mimetic examples) has also been found to be an influential factor in public sector reporting (Christensen, 2005). Thus, the search for legitimacy, coercive regulation requiring compliance, normative professionals (such as auditors' views), and mimetic examples of 'best practice' of service performance reporting are all plausible remedies to poor service performance reporting.

2 Contemporary institutional theory is based on neo-institutional theory with the incorporation of aspects of old institutional economics (DiMaggio and Powell, 1991; Fowler, 2009). 
The objective of this study is to investigate the effectiveness of specific interventions by analysing the service performance reporting of New Zealand local government entities. We focus on water supply service performance reporting within their long term plans (LTPs) (formerly known as long term council community plans or LTCCPs), from their first issue (2006) until 2012. We use disclosure indices to measure the reporting's conformity to the interventions' expectations and to identify the changes in disclosures over time. If the interventions are effective, then reporting should increasingly conform to expectations. Hence, our research provides useful insight to the literature as well as for regulators, as to the most effective tools for improving public sector service performance reporting. Further, these insights are from a jurisdiction which has had more than two decades' experience in service performance reporting.

The remainder of the paper is organised as follows. Section 2 describes the background to service performance reporting in New Zealand local governments and the interventions for the LTPs specifically. Section 3 presents the theoretical underpinning to this research and is followed by a section on the method used, in particular the disclosure index we developed. The final two sections provide the findings, discuss the implications and present future opportunities for research.

\section{Context -local government reporting}

Local governments represent a significant reporting tier with New Zealand's public sector. Eleven regional councils and 67 territorial authorities comprise this local government sector. The 67 territorial authorities include 12 city councils, 54 district 
councils, ${ }^{3}$ and Auckland Council ${ }^{4}$ (Department of Internal Affairs, 2014). Regional councils and territorial authorities are regarded as separate bodies but with complementary functions, rather than as two levels of sub-national government (Pallot, 2001). The regional councils' core function is environmental management, as regulated by environmental law. By contrast, the functions of territorial authorities include responsibility for a wide range of local infrastructure services including: water supply, sewerage, storm water, roads, environmental safety and health, and building control (Department of Internal Affairs, 2014). Each local government (regional and territorial) is required to be financially autonomous and, apart from grants for road construction and maintenance, local governments receive very little funding from central government. Their revenue derives primarily from property taxes (rates) and usercharges (Pallot, 2001) and they are required to be accountable to their ratepayers and other stakeholders (Local Government Act, 2002).

The objective of local governments' service performance reporting is to strengthen their accountability to the rate payers (NZICA, 2007). Indeed, planning and performance reporting are important mechanisms of accountability (Boyne, et al., 2002). Thus, the Local Government Act 2002 requires local authorities to prepare planning documents in the form of a long-term plan (LTP) which provides a basis, in financial and nonfinancial terms, for short term (annual) plans as well as to co-ordinate the local governments' various policies and plans. The actual achievements of local governments must also be reported against these plans in their annual report. Such

3 A territorial authority with a population in excess of 50,000 and predominantly urban, is designated as a city council (Local Government Act 2002, Schedule 3, s. 7).

4 On November 1, 2010, Auckland Council formed as an amalgamation of 8 former territorial authorities - Auckland City Council, Franklin District Council, Manukau City Council, North Shore City Council, Papakura District Council, Rodney District Council, and Waitakere District council. 
reporting is not required in New Zealand's corporate sector as, although the NPM reforms of the 1980s drew on private sector practices generally, for-profit entities can rely on profit as a performance measure (Thompson, 1995). ${ }^{5}$ On the contrary, in the public sector, financial results are only one aspect of demonstrating accountability, with non-financial performance information being integral to central and local government reporting (Barton, 1999; Gray, Owen, \& Adams, 1996; Hyndman \& Anderson, 1995). Therefore, it is unsurprising that there continues to be a push for public sector entities to disclose service performance information (Australian Accounting Standards Board, 2010; GASB2010; IPSASB2014; NZICA, 2007).

As local governments' annual reports report against their LTP, this plan forms the foundation for their reporting cycles. LTPs were first required in 2006. They must be prepared every three years - covering at least the following 10 years - and be audited by the OAG (Local Government Act 2002, ss.93, 94). A core section of LTPs is service performance planning, providing details on planned groups of activities or services. ${ }^{6}$ For each group of activities or services provided by local government, the LTP must include the following information:

- The activities within the group of activities or services;

- The rationale for delivery of the group of activities (including the community outcomes to which the group of activities or services contributes);

- Any significant negative effects that any activity within the group of activities or services may have on the local community;

\footnotetext{
5 Nevertheless, the rise of voluntary corporate social and environmental reporting is documented by, for example, Linnenluecke, Birt and Griffiths (2015) and Loh, Deegan and Inglis (2015).

6 The statutory services to be disclosed are water supply, wastewater, stormwater drainage, flood protection and control works, and the provision of roads and footpaths (Local Government Act, 2002, No. 84, as at July 1, 2011).
} 
- Performance measures that will enable the public to assess the level of service;

- Targets for each performance measure; and

- Financial information of the first 3 financial years covered by the plan.

(Local Government Act 2002, , Schedule 10).

Despite this mandatory requirement, and using the Act's requirement as a benchmark, the OAG announced that the first year of territorial authorities' LTPs reporting including service performance disclosures was unsatisfactory. In its role of scrutinizing and auditing, the OAG (2007) criticised the LTPs' reporting weaknesses in the Matters Arising from the 2006-16 Long-Term Council Community Plans. In particular for service performance reporting, the OAG (2007) criticised that the:

a) Rationale for council's activities did not clearly explain how the activities contributed to the community's outcomes and well-being.

b) Levels of service were not defined clearly.

c) Levels of service did not reflect the rationale of the activity.

d) Negative effects of the activity were not clearly stated.

e) Performance measures did not reflect the rationale.

f) Performance measures did not address negative effects.

g) Targets were not reasonable for 10-year estimates or improvements when compared to the activities' objectives.

In the second three year cycle (LTP 2009-19), the OAG (2010b) observed in Matters Arising from the 2009-19 Long-Term Council Community Plans that the 2009-19 LTPs showed general improvement over the 2006-16 LTPs. However, the OAG (2010a) was 
concerned that $(\mathrm{h})$ some activities were reported in aggregate with those that had little similarity in their objectives and service provision.

Additionally, in the same year, the OAG (2010a) compiled in Local Government Examples of Better Practice in Setting Local Governments' Performance Measures examples of better practice of performance measures by local governments used in various core services - water supply, roading, wastewater, libraries, and building control. For the example of water supply, the chosen performance measures were related to local governments':

i) Responsiveness to any poor quality water provided (for example where it was dirty, cloudy, smelly, bad tasting);

j) Management of water quality through compliance with New Zealand Water Standards and other standards.

k) Service responses to incidents.

1) Availability of water supply (lack of interruptions)

m) Management in terms of water flow and pressure.

n) Water conservation. This included saving water from leaking and wastage, provision of educational water conservation programme to communities, installing water metres to minimise the demand, and restriction programmes (especially during summer).

o) Support of firefighting services in terms of sufficient water supply and pressure for firefighting according to New Zealand Firefighting Standards.

Table 1 shows extracts of the better examples of performance measures of water supply for each type of performance measure (i) - o)) as specified in Local Government 

(OAG2010a).

[INSERT TABLE 1 HERE]

In the five to eight years following the Local Government Act (2002), the OAG's interventions sought to improve local government service performance reporting. However, the OAG's interventions, specifically the criticisms in 2007 (a) - g) above) and 2010 (h) - o) above), and the examples of better performance reporting issued in 2010, focus on different areas of the LTP. While the first two interventions (the OAG's criticisms in 2007 and 2010) focus on the need for territorial authorities to provide an overview of rationale, levels of service (see a) - h) above), performance measures, targets and aggregation of the service, the third intervention (examples of better performance reporting (OAG, 2010b)) specifically addresses performance measures. These measures are a subset of the 2007 and 2010 foci (see i) - o) above). Nevertheless, if they were effective, the influence of these three OAG interventions should be reflected in territorial authorities' LTPs over time. Thus, we would expect that the first criticism (OAG, 2007) would influence 2009-19 LTPs, and the second criticism (OAG, 2010a) and better practice examples (OAG, 2010b) would influence the subsequent 2012-22 LTPs. We sought to assess the effectiveness using longitudinal analysis. The theoretical framework will now be presented.

\section{Theoretical framework}

Contemporary institutional theory (from here on, institutional theory) takes a wide approach in explaining the factors that may effect a change in the practices of a set of 
organisations (DiMaggio \& Powell, 1983, 1991; Fowler, 2009; Greenwood \& Hinings, 1996; Mayer \& Rowan, 1977). It is particularly relevant to public sector studies, having been used by Meyer and Scott (1992) in their public education study, by Carpenter and Feroz (2001) and Fowler (2009) to describe legitimacy 'rituals' utilised by public sector organisations to demonstrate their worthiness. Loh et al. (2014) invoked this theory to inform their study of corporate social and environmental disclosure, while Mendel (2005) analysed the role of standards and their dispersion through similar entities. Contextually, as the environment in which organisations operate shape social reality (Scott, 1987); institutional theory enables an analysis of the changes that occur in those organisations as a result of changes within the wider social environment. In this research, NPM reforms, the accountability expectations and the OAG's power to direct reporting, all form part of the institutional framework in which local authorities present their statements of service performance and which can stimulate change over time.

In institutional theory, external factors are seen as a primary driver of changes in organisational practice. DiMaggio and Powell $(1983,1991)$ distinguished the external factors into three major pressures which can lead to changes in organisational behaviour: coercive powers (e.g. of legislation), mimetic or cognitive action (e.g. of best practices copied through networks) and normative ways (e.g. of professionals). Coercive forces include legislative requirements from regulatory/authoritative bodies. Mimetic processes occur when an organisation faces uncertainty in solving a problem and chooses to adopt the successful practices of another. As people reside in organisations, it also refers to the cognitive processes through which ideas are shared and diffused (Mendel, 2005). Normative influences stem primarily from professionalization whereby members of an occupation define the conditions and methods of their work to control their members - professionalizing activities would 
include education and incentive programs as well as standards (DiMaggio \& Powell, 1983; Mendel, 2005).

Various institutional theory studies have found coercive, mimetic and normative pressures influence public sector entities' accounting practice (Mayer \& Scott, 1992). Coercive pressure from authoritative requirements (legislation and accounting standards) significantly impacted the accounting practices of Australian government departments (Hoque, 2008). Similarly, coercive pressure from standard setters/regulators was believed to improve the deficient financial reporting of Australia not-for-profit entities (Palmer, 2013). Two Australian studies show that mimetic pressures were chiefly responsible for government acceptance of accrual accounting from the for-profit sector (Christensen, 2005) and for gambling companies to imitate each other ("following best practice") in disclosing their corporate social responsibility (Loh et al., 2014, p. 32). All the three pressures appeared to be forceful factors on nonfinancial performance measurement practices in Japanese banks (Hussain \& Hoque, 2002). However, Carpenter and Feroz (2001) argue that the effect of these pressures on accounting practice may vary, based on other supporting factors such as key decision-makers' beliefs, culture and professional expertise.

These studies provide examples of ways in which individual institutions react to changes in the environment in order to obtain resources to survive (Carpenter and Feroz, 2001). New Zealand's environment - in particular its institutional arrangements - seeks to reduce agency costs and to add legitimacy to annual reporting (Hay, 2003). It is therefore likely that institutional forces identified within New Zealand's local government environment will influence the service performance reporting of local authorities. The Local Government Act (2002) requirements are an obvious coercive pressure on local governments to report (especially the requirements in Schedule 10, 
see above). However, this Act has remained largely unchanged and was found to be weak in providing adequate guidance for service performance reporting in other research (Keerasuntonpong, 2011). Therefore, other interventions (mimetic and/or normative) may complimentarily promote the change in the quality of service performance disclosures in LTPs.

Legitimacy theory is also used by researchers to explain improved disclosure quality (e.g. Loh et al., 2014; Deegan \& Rankin, 1996). Organisations will adopt new practices or values of society in order to gain or maintain legitimacy. The failure of complying with social expectations or being legitimate may threaten organizational survival (Dowling and Pfeffer, 1975). In line with Mulgan (1997) and Wimbush (2011), the OAG's professional criticisms plays a major role in public sector entities understanding the implications of successful reporting; that is, continued legitimacy and the fulfilment of accountability expectations, as the OAG is the professional accounting officer appointed by New Zealand's Parliament. The failure to comply with the OAG's criticism may create adverse publicity and jeopardise local authorities' legitimacy. This threat provides a pressure for territorial authorities to incorporate the OAG's criticism (Mulgan, 1997)

The first two OAG interventions (i.e. the OAG's (2007) criticisms) represent normative pressures on local governments as well as challenges to their legitimacy. Additionally, the third intervention, (OAG, 2010b, providing examples of better practice in setting performance measures) presents a potential mimetic pressure by highlighting 'best practice' to local governments to improve their accountability discharge through better reporting.

Theoretically, such mimetic and normative factors and the seeking of legitimacy, would provide effective pressures to improve service performance reporting within LTPs in a static legislative (coercive) environment. That is, the disclosures within 2009-19 and 
2012-22 LTPs should change following the first two OAG interventions (OAG 2007, 2010) and the disclosures within 2012-22 LTPs should incorporate the better practice provided by the third intervention (OAG, 2010b). Figure 1 presents our hypotheses of the influence of these interventions.

\section{[INSERT FIGURE 1 HERE]}

\section{Methodology}

The study focuses on water supply service performance disclosures within territorial authorities' LTPs and the interventions of the OAG to improve that reporting. Analysis of annual reports is a common method to research disclosure issues such as service performance (Loh et al., 2014) and these LTPs include both financial and service performance reporting. Water supply is one of the six core statutory services and must be disclosed under the Local Government Act 2002 (No. 124, Schedule 10, Part 1, s. 2). The requirement to report service performance in respect of water supply, makes it possible to compare the performance reporting of all local authorities, and also to analyse any changes in that reporting as a result of the OAG $(2007,2010 \mathrm{~b}, 2010 \mathrm{a})$ interventions. The LTPs reported on 2006-16, 2009-19, and 2012-22 were downloaded from all 67 territorial authorities' websites. Those that were not available online were accessed from the National Library either from its electronic archive or in hardcopy from its Wellington archive.

\subsection{Content analysis}

Content analysis, as a structured method to analyse annual reports, is replicable and also leads to valid inferences from the data (Krippendorf, 1980). It is widely used in 
conjunction with a disclosure index to guide the content analysis and inferences gained. First we explain the item selection and scoring system within the content analysis which was developed to deal with the variety of disclosure made.

In order to examine the impact of the OAG's interventions, items were selected from water supply disclosures, based on:

Intervention 1: the OAG's (2007) criticisms in Matters Arising from the 2006-16 Long-Term Council Community Plans;

Intervention 2: Matters Arising from the 2009-19 Long-Term Council Community Plans (OAG2010b); and

Intervention 3: the better practice in Local Government Examples of Better Practice in Setting Local Governments' Performance Measures (OAG2010a) which included performance measures for water supply.

Tables 2, 3, and 4 provide the intervention items (using water supply disclosures), and the criteria used for scoring.

[INSERT TABLE 2 HERE]

[INSERT TBALE 3 HERE]

[INSERT TABLE 4 HERE]

Scoring is an important factor. Dichotomous scoring may result in extreme aggregation and reduce the ability of the researcher to reward particularly detailed reporting; however, it potentially avoids researcher subjectivity (Williams, 2001). To minimize subjectivity in assessment and the temptation to reward entities that provide significant 
detail rather than targeted information, we used three levels of scoring: 0, 1, 2. A score of 2 was applied if the reporting fully meeting the criteria; 1 if it moderately met the criteria; and; 0 if the reporting was absent. This scoring differentiates between positive and negative disclosures only in respect of f) above; in all other respects there was no differentiation. Prior research has found entities tend to prioritise good news when reporting (e.g. Loh et al., 2014), but we were not attempting to measure the quality of the service, rather the quality of the disclosure.

We used the disclosure criteria in Tables 2, 3, and 4 for scoring the LTPs. Following the individual scoring, we aggregated the item scores assigned for each authority to quantify an index. To increase the scoring validity, two researchers (an author and independent researcher of the author team) scored the disclosures. Each discrepancy was discussed between the two researchers and all discrepancies were able to be resolved as well as clarifying the criteria. From Table 2, some items may not have been available to be scored and therefore were assessed as "Not Applicable" (N/A). In particular, a number were conditional on the presence of another related item. These items are c), e), and f). If the rationale was not provided, the items c) and e) were scored as N/A. Similarly, item $\mathrm{f}$ ) received N/A if the negative effect of water supply was not provided.

Based on the analysis of the LTPs, we found that a number of territorial authorities use more than one performance measure so as to provide more examples of the same type of performance measure. This is in line with Intervention 3 (OAG, 2010b), which gave between 2-5 performance measures for each type of item. In prior UK research, Pendlebury, Jones, and Karbhari (1994) found that otherwise limited efficiency information was enhanced when public sector entities used more than one indicator in reporting the efficiency of their performance. Due to the multiple aspects of water 
supply and the need for clarity, this prior study provides support for our stance in scoring the maximum 2 when the item had more than one relevant measure.

\subsection{Disclosure index}

In order to assess the change over time, disclosure indices were developed from the scored items. A disclosure index is a popular instrument used by various researchers to measure the extent of information disclosed by organisations. A number of public sector studies use indices to examine both financial and non-financial disclosures (Buzby, 1975; Cooke, 1989; Coy, Tower, \& Dixon, 1994; Pendlebury, et al., 1994; Robbins \& Austin, 1986; Ryan, et al., 2002; Smith \& Coy, 2000; Stanley, Jennings, \& Mack, 2008; Taylor \& Rosair, 2000). Some studies use disclosure indices for specific disclosures - for example, disclosures about the entity's environmental performance (Clarkson, Li, Richardson, \& Vasvari, 2008; Hughes, Anderson, \& Golden, 2001; Wiseman, 1982), intellectual capital (Bozzolan, O'Regan, \& Ricceri, 2006; Schneider \& Samkin, 2008; Williams, 2001) and service performance information (Boyne \& Law, 1991; Keerasuntonpong, 2011).

In analysing the impact on the LTPs of the OAG's criticism (2007), each scored item from a) - g) was totalled into an Index (1) representing all the three years of LTPs. To test the longitudinal change in the LTP disclosures between 2006 and 2009, 2009 and 2012, and 2006 and 2012 for each item a) - g), Wilcoxon Signed Ranks Test was used. This non-parametric test could show if the two samples' (different years') mean ranks differ. As data are paired from the same population of reporters, and measured on an ordinal scale, the Wilcoxon Signed Test is appropriate (Zikmund, 2003). To view the change in Index (1), a parametric test (paired samples t-test) was used. We hypothesized that, if effective, the OAG's (2007) criticism items' scores and the Index (1) would significantly increase in 2009-2019. 
Similarly, for intervention $2(\mathrm{OAG}, 2010 \mathrm{a})$, item $\mathrm{h}$ ) was scored $0-2$, for all the three years and the paired differences Wilcoxon Signed Test was used to analyse the results (see Table III). Since h) is only one item, the score of the item is an index of itself. We hypothesized that, if effective, the score of the OAG's (2010a) would significantly increase in the 2012-2022 reporting. A positive result would also provide evidence of successful normative pressure from the OAG's intervention 2. Together with the OAG's first intervention, we could expect that the scores would positively increase from 2006 - 2009 and remain largely unchanged from 2009 - 2010, as that would provide more robust support for an argument of the OAG's normative pressure on territorial authorities' reporting. However, if the results are insignificant, that may identify that the normative pressures alone are not sufficient to change the territorial authorities' accounting practice.

In respect of analysing the impact on the LTPs of the OAG's (2010b) intervention 3, each item from i) - o) was scored from $0-2$ and the scores of i) - o) items were totalled into Index (2), for all the three years of LTPs. To test the change across years from the disclosures between 2006 - 2009, 2009 - 2012, and 2006 -2012 for each item (i) - o)), Wilcoxon Signed Ranks Test was again used to test the differences in the nonparametric data. To view the change of the Index (2), a parametric test (paired samples t-test) was again used. It is expected that the OAG's (2010b) third intervention's scores and the Index (2) should significantly increase in 2012-2022 LTPs.

\section{Results}

There are 67 territorial authorities, however the Christchurch City Council could not provide its LTP for 2012-22 due to the 2011/2012 earthquakes. Therefore, LTPs of 66 territorial authorities were accessed. Table 5 provides the Wilcoxon Signed Ranks Test statistics for $Z$ and significant scores for each of the items a) - o) evaluated for 
the three comparing years. A positive Z-score reflects improvement in the later year than the early year. A negative Z-score reflects poorer reporting in the later year than in the early year. In all cases, it was expected the Z-score will be positive if the normative and mimetic pressures are effective. Table 6 provides the Paired Samples Test of the Index 1 and Index 2.

[INSERT TABLE 5 HERE]

[INSERT TABLE 6 HERE]

From Table 5, it can be seen there is a significant increase from 2006 to 2009 and 2006 to 2012 in item d) "negative effects of water supply services" with $p=.022$ and .003 , and item g) "targets are reasonable for 10 year estimates" with $\mathrm{p}=.000$ and .000 respectively. In 2009 and 2012, territorial authorities provided more disclosures on the negative effects on health, economic and environment from improperly provided water services (d). They also expected to achieve higher performance measure targets in the future 10 years $(\mathrm{g})$. The score of other items $(\mathrm{a}, \mathrm{b}, \mathrm{c}, \mathrm{e}, \mathrm{f})$ which were also criticized by the OAG (2007) largely remained the same across the years of comparison (they were not statistically different).

Nevertheless, the Index (1) based on the OAG's (2007) criticism significantly increased from 2006 to 2009, $\mathrm{p}=.001$ (see Table 6). The significant increase in two of the OAG's (2007) criticism item scores (d) and g)) and the Index (1) from 2006 to 2009 indicates that the OAG's (2007) criticism effectively improved water supply disclosures of local governments in New Zealand in that first period. 
From Table 5, the practice of aggregating the reporting of water supply with other activities (item h)) significantly decreased from year 2009 to $2012(\mathrm{p}=.000)$ and between 2006 and $2012(\mathrm{p}=.003$ ) (that is, the 2006 and 2009 scores are lower than the 2012 score). This would allow them to avoid the criticism of combining reporting on activities that had little in common. This potentially indicates that the OAG's 2010 criticisms had a positive impact on the subsequent cycle's disclosures.

The items' i) - o) scores based on better practice examples, from Table 5, and the Index (2) were expected to increase in 2012 in responding to the OAG's (2010b) third intervention providing examples of 'good practice'. However, it can be seen from Table 5 (in respect of items i) - o)), that the changes were mainly insignificant. The items that changed significantly were item m) "Water flow and pressures", item n) "Water conservation" and (from Table 6,) Index (2). Disclosures on these performance measures were significantly poorer quality in 2012 than $2009(\mathrm{p}<.05)$ which is contradictory to the study's expectation. If the examples of better practice were effective in mimetically encouraging better practice, this score should have increased significantly from 2009 to 2012. The Index (2), consequently, confirms that the example of better performance measures issued in 2010 had no significant impact on the following reporting years in 2012 (see Table 6$)(\mathrm{p}<0.05)$. This provides evidence that mimetic pressure did not impact local government reporting practice and this may be due to the lack of authoritative requirement or urgency to adopt the better practice examples. $^{7}$ 
Figure 2 summarises these results of the impact (or otherwise) of the interventions. While the OAG's 2007 and 2010 criticisms positively influenced local authorities' water service performance reporting, the better practice examples did not.

[INSERT FIGURE 2 HERE]

\section{Discussion and Conclusions}

Drawing on contemporary institutional and legitimacy theories, we examined how normative and mimetic pressures influence the service performance reporting of New Zealand local government at a time when coercive pressures were held constant. We scored the content of LTPs and analysed two normative interventions longitudinally: the OAG's (2007) criticisms (following the first LTPs) and (after the second LTPs) (OAG2010b). These criticisms also threatened local government's legitimacy. The mimetic intervention analysed was the discussion paper providing examples of best practice also issued (after the second LTPs) (OAG2010a). We focused on water supply service performance information within the long-term plans (LTPs) in their three consecutive reporting periods, from their first publication in 2006 to the most recent year in 2012. The disclosure indices we developed identified the changes in disclosure quality over time.

Our study reveals that the disclosures in 2009 and 2012 conform well to the Office of Auditor-General's criticisms in both 2007 and 2010a, respectively. Index (1) which measures the conformity of the LTPs to the OAG's 2007 criticisms shows a significant increase (better reporting) from LTPs 2006-16 to 2009-19. Most territorial authorities increased their disclosures of d) "negative effects of water supply", and g) "reasonable 
targets" while the other items of Index (1) remained largely the same. This may be due to the fact that local authorities perceive that these items (d), g)) are more important than the others and are of interest to their local communities who would hold them accountable for the negative effects of poor water supply and the achievement of targets to improve it. The score which measures reporting in aggregating water supply reporting to other non-related services shows that most local authorities separate water supply service into an individual activity rather than combine it with other services in the 2012-22 LTPs. It is possible that territorial authorities perceive that water supply is an important standalone service which their local communities would be interested to read about separately and this is in line with it being a service which territorial authorities are required to report on under the Local Government Act (2002).

This result provides evidence that the OAG's criticisms were effective normative interventions which improved New Zealand local governments' service performance reporting. The conformity of the LTPs to the OAG's criticisms is also consistent with Mulgan (1997) and Wimbush (2011) who highlight the important role of scrutinizing or reviewing parliamentary officers (such as the OAG) for improving accountability of public sector entities, due to the threats to the legitimacy of public sector entities. In light of the international push to public sector service performance reporting, we recommend that parliamentary officers' scrutiny (including from Auditors-General) be published to emphasise their legitimating role (Cohan and von Staden, 2003; Loh et al, 2014).

On the contrary, the result of Index (2) shows that the disclosures in 2012 do not conform to the OAG's (2010b) examples of better reporting practice. In our study, the unsuccessful influence of mimetic pressure is contradictory to Christensen (2005) who found the mimetic pressure was significant in the adoption of accrual accounting by 
Australian public sector entities. It is possible that local governments do not perceive the importance of performance measures suggested by the examples (Lee, 2008), or that one or more of the factors identified by other researchers reduces their ability to report for example, lack of staff, staff expertise, financial resources, and data availability (Boyne, et al., 2002; Boyne \& Law, 1991; Christiaens, 1999; Ingram, 1984). Further research is necessary to elaborate on this.

Our results suggest that mimetic pressure alone was ineffective in improving local governments' service performance reporting, without normative and/or coercive support. Provided that performance measures are a common international concern of service performance reporting by various jurisdictions, the result suggests that regulators may choose to emphasise other initiatives - normative, coercive, or aimed at legitimacy - rather than mimetic tools to improve reporting of the performance measures. Combining pressures while also threatening local government legitimacy can add to their effectiveness.

Nevertheless, these interventions may have suffered from being too general. We found that some items (d), g)) improved but other items (a), b), c), e), f)) did not. It may have been more effective for the OAG (2010a) to have contrasted areas that had improved with those requiring more work. Instead of monitoring these areas more carefully, the 2010 criticism focused on a new area. This resulted in more appropriate aggregation of water supply reporting but did not result in other items (a), b), c), e), f)) in Table 5 improving.

This research is useful to other jurisdictions pursuing service performance reporting because the New Zealand reporting experience shows how, even in a coercive environment, other initiatives, particularly normative pressures combined with threats to legitimacy are required to ensure reporting improvement. Further, this research adds 
to theory by suggesting a complementary interdependence within institutional theory. Other researchers have found that coercive pressure alone has not resulted in high quality reporting (Hoque, 2008), while the evidence in this research shows that normative pressure in tandem with coercive pressure can be a catalyst for the evolution towards better reporting.

Although there are limitations in this study, as it focuses on water supply disclosures in one country, nevertheless, water supply services are considered a critical service of local authorities and are required to be reported on by all New Zealand local authorities. Therefore, the capability of reporting water supply is expected to extend to other activities' disclosures as well. It appears to be important for government, through the $\mathrm{OAG}$, to take a multiple-pronged approach in order to encourage better service performance reporting through examples as well as criticism. However, changes are not instant and require some time to take effect.

The results open up future opportunities to investigate changes in performance reporting in other jurisdictions. This is important in light of the integral nature of service performance reporting in discharging accountability (Barton, 1999; Gray, Owen, \& Adams, 1996; Hyndman \& Anderson, 1995), the introduction of regulation by standard setters (Australian Accounting Standards Board, 2010; GASB2010; IPSASB2014; NZICA, 2007), and the evidence of poor reporting in this research and prior research (Boyne \& Law, 1991; Ellig, 2007; Foltin, 1999; Ho \& Ni, 2005; N. Hyndman \& Anderson, 1995; N. Hyndman \& Eden, 2002; Keerasuntonpong, 2011; Kloot, 2009; Lee, 2006, 2008; Lonti \& Gregory, 2007; Ryan, et al., 2002; Smith \& Coy, 2000; Steccolini, 2004; Thompson, 1995; Tooley \& Guthrie, 2001). If reporting is to be improved, then the most effective interventions to do so must be given priority. 


\section{References:}

Australian Accounting Standards Board (2010), Report on staff research into domestic and international requirements and practices relating to service performance reporting. Boyne, G., J. Gould-Williams, J. Law, and W. Richard, 2002, Plans, performance information and accountability: The case of best value, Public Administration, 80, 691710.

Boyne, G., and J. Law, 1991, Accountability and local authority annual reports: The case of Welsh District Councils, Financial Accountability \& Management, 7, 179-195. Bozzolan, S., P. O'Regan and F. Ricceri, 2006, Intellectual capital disclosure (ICD); A comparison of Italy and the UK, Journal of Human Resource Costing \& Accounting, $10,92-113$.

Buzby, S., 1975, Company size, listed versus unlisted stocks, and the extent of financial disclosure, Journal of Accounting Research, 13, 16-37.

Cahan, S. F., and C. J. van Staden, 2009, Black empowerment, legitimacy and the value added statement: evidence from post-apartheid South Africa, Accounting \& Finance, $49,37-58$.

Carpenter, V., and E. Feroz, 2001, Institutional theory and accounting rule choice: an analysis of four US state governments' decisions to adopt generally accepted accounting principles, Accounting, Organizations and Society, 26, 565-596.

Christensen, M., 200), The 'Third Hand': Private Sector Consultants in Public Sector Accounting Change, European Accounting Review, 14, 447-474.

Christiaens, J., 1999, Financial accounting reform in Flemish municipalities: An empirical investigation, Financial Accountability and Management, 15, 21-40. 
Clarkson, P., Y. Li, G. Richardson and F. Vasvari, 2008, Revisiting the relation between environmental performance and environmental disclosure: An empirical analysis, Accounting, Organizations and Society, 33, 303-327.

Cooke, T. E., 1989, Disclosure in the corporate annual reports of Swedish companies, Accounting and Business Research, 19, 113-124.

Coy, D., G. Tower and K. Dixon, 1994, Public sector reform in New Zealand: The progress of tertiary education annual reports, 1990-1992, Financial Accountability \& Management, 10, 253-261.

Deegan, C. and M. Rankin, 1996, Do Australian companies report environmental news objectively? An analysis of environmental disclosures by firms prosecuted successfully by the environmental protection authority. Accounting, Auditing and Accountability Journal, 9, 50-67.

Department of Internal Affairs, 2014, Local Government in New Zealand - local councils, $\quad$ Retrieved June, 2014, from http://www.localcouncils.govt.nz/lgip.nsf/wpg_URL/About-Local-GovernmentIndex?OpenDocument

DiMaggio, P. and W. Powell, 1983, The iron cage revisited: Institutional isomorphism and collective rationality in organizational fields, American Sociological Review, 48, $147-160$.

DiMaggio, P. and W. Powell, 1991, Introduction. In The New Institutionalism in Organizational Analysis. (University of Chicago, Chicago, Ill).

Dixon, J., A. Kouzmin and N. Korac-Kakabadse, 1998, Managerialism - something old, something borrowed, little new economic prescription versus effective organizational 
change in public agencies, The International Journal of Public Sector Management, 11, $164-187$.

Dowling, J. and J. Pfeffer, 1975, Orgnizational legitimacy: Social values and organizational behavior, Pacific Sociological Review, 18, 122-136.

Ellig, J., 2007, Scoring government performance reports, The Public Manager, 36, 38.

Foltin, C., 1999, State and local government performance: It's time to measure up!, The Government Accountants Journal, 48, 40-46.

Fowler, C., 2009, Performance management, budgeting, and lgitimacy in primary educational organisations, Journal of Accounting and Organizational Change, 5, 168196.

Glynn, J., and D. Perkins, 1997, Control and accountability in the NHS market: a practical proposition of logical impossibility?, International Journal of Public Sector Management, 10, 62-75.

Governmental Accounting Standards Board, 2010, GASB Issues Suggested Guidelines for Voluntary Reporting of Service Efforts and Accomplishments (SEA) Performance Information, Retrieved June, 2014, from http://www.gasb.org/cs/ContentServer?c= GASBContent_C\&pagename=GASB\%2FGASBContent_C\%2FGASBNewsPage\&ci $\mathrm{d}=1176157102416$

Greenwood, R. and C. Hinings, 1996, Understanding radical organizational change: bringing together the old and the new institutionalism, Academy of Management, 21, 1022-1043.

Hay, D., 2003, Knowledge transfer costs and dependence as determinants of financial reporting, Accounting \& Finance, 43, 311-330. 
Ho, A. and A. Ni, 2005, Have cities shifted to outcome-oriented performance reporting?-A content Analysis of city budgets, Public Budgeting \& Finance, 25, 61-83. Hoque, Z., 2008, Measuring and reporting public sector outputs/outcomes, International Journal of Public Sector Management, 21, 468-493.

Hughes, S. B., A. Anderson and S. Golden, 2001, Corporate environmental disclosures: are they useful in determining environmental performance? Journal of Accounting and Public Policy, 20, 217-240.

Hussain, M. and Z. Hoque, 2002, Understanding non-financial performance measurement practices in Japanese banks, Accounting, Auditing \& Accountability Journal, 15, 162-183.

Hyndman, N., and R. Anderson, 1995, The use of performance information in external reporting: An empirical study of UK executive agencies, Financial Accountability \& Management, 11, 1-17.

Hyndman, N., and R. Eden, 2002, Executive agencies, performance targets and external reporting, Public Money \& Management, 18, 23-30.

Ingram, R. W., 1984, Economic incentives and the choice of state government accounting practices, Journal of Accounting Research, 22, 126-144.

International Public Sector Accounting Standard Board, 2014, Proposed Recommended Practice Guideline: Reporting Service Performance Information.

Keerasuntonpong, P., 2011, Examination of statements of service performance of New Zealand local authorities: The case of wastewater services. Unpublished $\mathrm{PhD}$ Thesis, Victoria University of Wellington, Wellington. 
Kloot, L., 2009, Performance measurement and accountability in an Australian fire service', International Journal of Public Sector Management, 22, 128-145.

Krippendorf, K., 1980, Content Analysis: an Introduction to Its Methodology (Sage, Beverly Hills, CA).

Lee, J., 2006, Performance reporting by Australian government trading enterprises: An empirical study 1998-2002, Australian Accounting Review, 16, 34-48.

Lee, J., 2008, Preparing performance information in the public sector: An Australian perspective, Financial Accountability \& Management, 24, 117-149.

Linnenluecke, M. K., J. Birt, and A. Griffiths, 2015, The role of accounting in supporting adaptation to climate change, Accounting \& Finance, forthcoming.

Local Government Act 2002.

Loh, C. M., C. Deegan and R. Inglis, 2014, The changing trends of corporate social and environmental disclosure within the Australian gambling industry, Accounting \& Finance, forthcoming.

Lonti, Z., and R. Gregory, 2007, Accountability or countability? Performance measurement in the New Zealand public service, 1992-2002, Australian Journal of Public Administration, 66, 468-484.

Mayer, J., and B. Rowan, 1977, Institutionalized organizations: formal structure and myth and ceremony, American Journal of Sociology, 83, 340-363.

Mayer, J., and W. Scott, 1992, Organizational environments: Ritual and rationality. Newbury Park, CA: Sage Publications.

Mendel, P. J., 2005, International Standardization and Global Governance: The spread of quality and environmental management standards. In A. J. Hoffman \& M. J. 
Ventresca (Eds.), In Organizations, Policy and the Natural Environment: Institutional and Strategic Perspectives.

Mulgan, R., 1997, The processes of public accountability, Australian Journal of Public Administration, 51, 35-41.

Neale, A., and J. Pallot, 2001, Frontiers of non-financial performance reporting in New Zealand, Australian Accounting Review, 11, 27-34.

New Zealand Institute of Chartered Accountants (NZICA), 2007, Technical Practice Aid No.9 Service Performance Reporting. Wellington: New Zealand Institute of Chartered Accountants.

Office of the Auditor-General (OAG), 2007, Matters arising from the 2006-16 LongTerm Council Community Plans. Wellington: The Office of Controller and AuditorGeneral.

Office of the Auditor-General (OAG), 2008, The Auditor-General's observations on the quality of performance reporting. Wellington: Office of the Auditor-General.

Office of the Auditor-General (OAG), 2010b, Local government: Examples of better practice in setting local authorities' performance measures. Wellington: The Office of Controller and Auditor-General.

Office of the Auditor-General (OAG), 2010a, Matter arising from the 2009-19 longterm council community plans. Wellington: The Office of Controller and AuditorGeneral.

Olson, O., J. Guthrie and C. Humphrey, 1998, Global warning: Debating international developments in new public financial management. Oslo: Cappelen Akademisk Forlag. 
Pallot, J., 1998, The New Zealand revolution. In O. Olson, J. Guthrie \& C. Humphrey (Eds.), Global warning: Debating international developments in new public financial management. Oslo: Cappelen Akademisk Forlag.

Pallot, J., 2001, Local government reform in New Zealand: Options for public management as governance: University of Canterbury.

Palmer, P., 2013, Exploring attitudes to financial reporting in the Australian not-forprofit sector. Accounting and Finance, 53, 217-241.

Parker, L., and G. Gould, 1999, Changing public sector accountability: Critiquing new directions. Accounting Forum, 23, 109-136.

Pendlebury, M., R. Jones and Y. Karbhari, 1994, Developments in the accountability and financial reporting practices of executive agencies, Financial Accountability \& Management, 10, 33-46.

Robbins, W., and K. Austin, 1986, Disclosure quality in governmental financial reports: An assessment of the appropriateness of a compound measure, Journal of Accounting Research, 24, 412-421.

Ryan, C., T. Stanley and M. Nelson, 2002, Accountability disclosures by Queensland local government councils: 1997-1999, Financial Accountability \& Management, 18, 261-289.

Schneider, A., and G. Samkin, 2008, Intellectual capital reporting by the New Zealand local government sector, Journal of Intellectual Capital, 9, 456-486.

Smith, S., and D. Coy, 2000, The quality of city council annual reports, 1996-97 \& 1997-98, The University of Waikato Working Paper no. 64. 
Stanley, T., N. Jennings and J. Mack, 2008, An examination of the content of community financial reports in Queensland local government authorities, Financial Accountability \& Management, 24, 411-138.

Steccolini, I., 2004, Is the annual report an accountability medium? An empirical investigation into Italian local governments, Financial Accountability \& Management, $20,327-351$.

Taylor, D., and M. Rosair, 2000, The effects of participating parties, the public and size on government departments' accountability disclosures in annual reports, Accounting, Accountability \& Performance, 6, 77-97.

Thompson, G., 1995, Problems with service performance reporting: The case of public art galleries, Financial Accountability \& Management, 14, 337-350.

Tooley, S., and J. Guthrie, 2001, Performance accountability disclosures in annual reports: An application in the New Zealand compulsory school sector. Paper presented at the Third Asian Pacific Interdisciplinary Research in Accounting, University of Adelaide: Australia.

Williams, S., 2001, Is intellectual capital performance and disclosure practice related? Journal of Intellectual Capital, 2, 192-203.

Wimbush, E., 2011, Implementing an outcomes approach to public management and accountability in the UK - are we learning the lessons? Public Money \& Management, $31,211-218$.

Wiseman, J., 1982, An evaluation of environmental disclosures made in corporate annual reports, Accountability, Organizations and Society, 7, 53-63.

Zikmund, W., 2003, Business Research Methods. Ohio: Thomson South-Western. 
Figure 1: Summary of the expectation of the influence of the initiatives on the disclosures

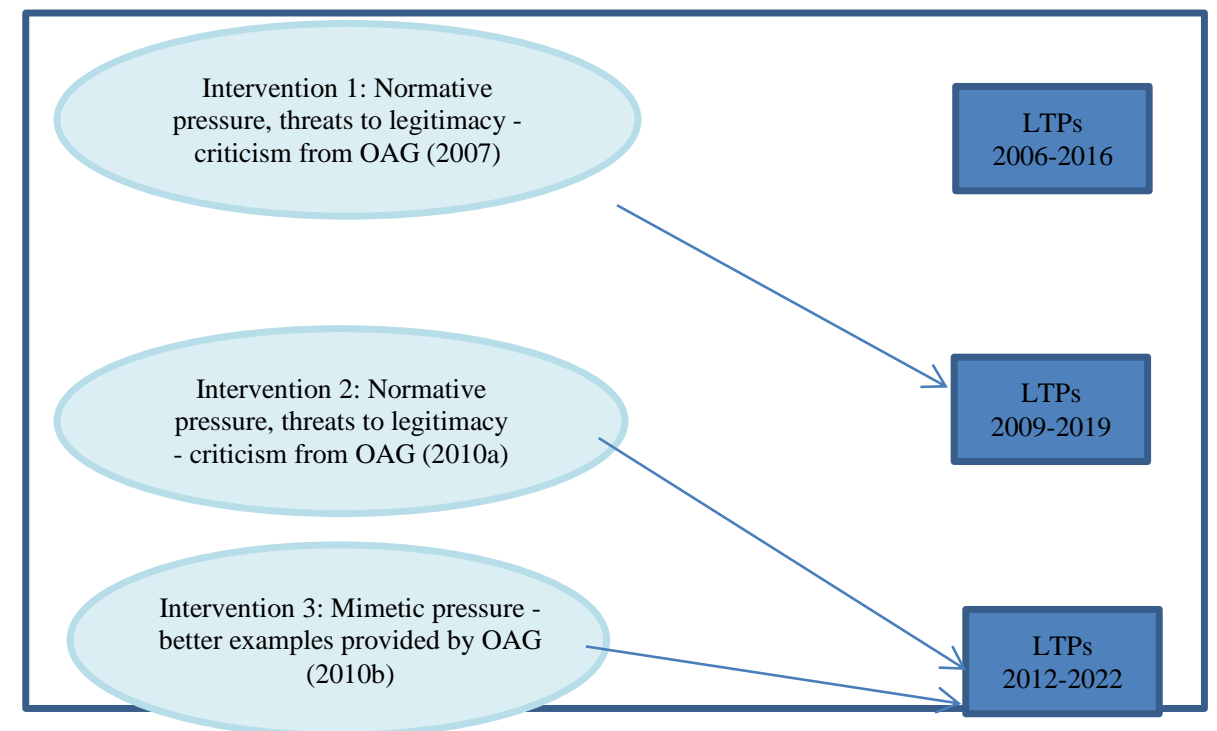

Figure 2: Summary of the result of the influence of the initiatives on the disclosures

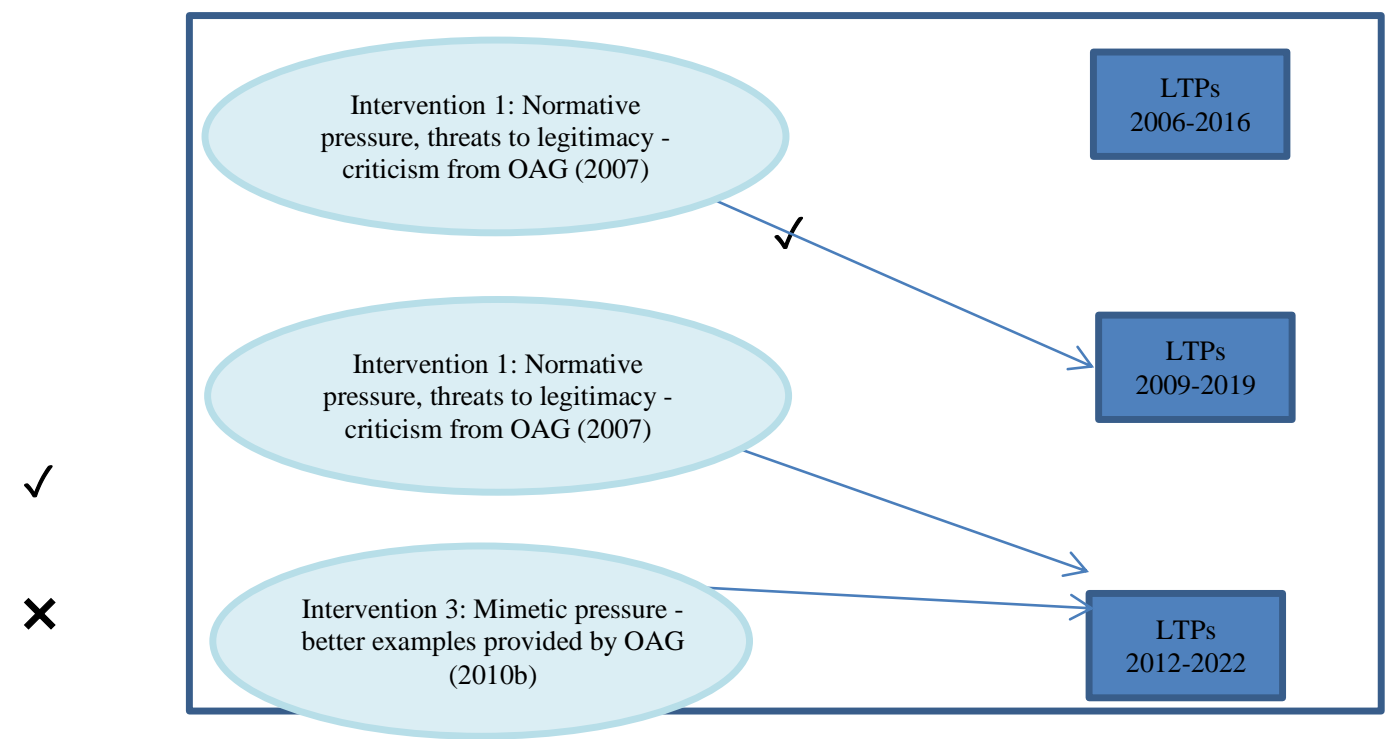


Table 1: Better examples of performance measures of water supply

(i) Water quality responsiveness:

- $\quad \%$ of urgent requests for service responded to within one day (due to dirty, cloudy, smelly or bad testing water).

- Issue "boil water" notices within $[\mathrm{x}]$ time of a detected health and safety risk.

(j) Quality of water supply:

- Compliance with microbiological criteria of DWSNZ: no detectable E-coli in water leaving water treatment plant; and no E-coli in [x]\%of the distribution sample.

- $\%$ compliance with E-coli criteria for priority one bacteriological determinant of DWSNZ. As measured by the number of samples required by the DWSNZ.

- Council supplies drinking water that meets the Ministry of Health As water quality standards to all customers.

(k) Local governments' service responses to incidents:

- $\quad \mathrm{X} \%$ of repairs and system failures responded to within 4 hours.

- X hours response for water reticulation faults and emergencies

(1) Water supply availability (lack of interruptions):

- X minutes of major loss of supply creating a situation causing or likely to cause damage to persons or property.

- X minutes for substantial leaks not falling into the first priority

(m) Water flow and pressures management:

- Flow rate meets stated levels of service for each customer group.

- Flow rate is to exceed specified minima.

- Minimum flow rates are:

-Urban $[\mathrm{x}] \mathrm{L} /$ minute, - Rural $[\mathrm{x}] \mathrm{L} /$ minute (on demand), -rural $[\mathrm{x}] \mathrm{L} / \mathrm{day}$ (restricted

flow)

- Pressure exceeds specified minima for each customer group.

- The minimum pressures are:

-Urban properties: [x]kPa, -Rural properties: $[\mathrm{x}] \mathrm{kPa}$

(n) Water conservation:

- $\quad$ Repair to Leaking pipes

- Consumption reduces by $\%$ per annum

- Peak water consumption of water not more than [x] litres per person per day.

- Number or percentage participating in water conservation programmes.

- $\quad$ Percentage of participant satisfies with education programmes.

(o) Firefighting:

- $\quad \%$ of compliance with minimum firefighting pressures at not less than $[\mathrm{x}]$ randomly selected fire hydrants tested annually.

- The water reticulation system shall be able to provide the following firefighting flows from hydrants except in $[\mathrm{x}]$ and $[\mathrm{x}]$ township:

-Residential zone: $[\mathrm{x}] \mathrm{L} / \mathrm{second}$,

-Commercial zone:[x]L/second, -Industrial zone: $[\mathrm{x}] \mathrm{L} / \mathrm{second}$

- $\quad \%$ of residential properties that have a proximity to fire hydrants as required by the NZ Fire Service Fire Fighting Water Supplies Code of Practice (currently two hydrants within a[x]m radius).

- $\quad \%$ of urgent requests for service responded to within one day. 
Table 2: Criteria for evaluation of territorial authorities' water supply disclosures based on Intervention 1: the OAG's (2007) criticism

\begin{tabular}{|c|c|c|c|c|}
\hline \multirow{2}{*}{\multicolumn{2}{|c|}{ Items }} & \multicolumn{3}{|c|}{ Criteria for Scoring } \\
\hline & & $\mathbf{0}$ & 1 & 2 \\
\hline a) & $\begin{array}{l}\text { Rationale for council's water } \\
\text { supply services }\end{array}$ & Not provided & Moderately explained & Fully explained \\
\hline b) & Levels of water supply services & Not provided & Explained descriptively & $\begin{array}{l}\text { Explained descriptively } \\
\text { and with qualitative } \\
\text { information (eg. Number } \\
\text { of bores or schemes) }\end{array}$ \\
\hline c) & $\begin{array}{l}\text { Levels of service reflect rationale } \\
\text { of the activity }\end{array}$ & $\begin{array}{l}\text { Not reflecting } \\
\text { the rationale }\end{array}$ & $\begin{array}{l}\text { Reflecting less than half } \\
\text { of the rationale }\end{array}$ & $\begin{array}{l}\text { Reflecting more than half } \\
\text { of the rationale }\end{array}$ \\
\hline d) & $\begin{array}{l}\text { Negative effects of water supply } \\
\text { services }\end{array}$ & Not provided & $\begin{array}{l}\text { Negative effects not } \\
\text { provided but risks are } \\
\text { identified }\end{array}$ & $\begin{array}{l}\text { Negative effects are } \\
\text { provided }\end{array}$ \\
\hline e) & $\begin{array}{l}\text { Performance measures reflect the } \\
\text { rationale. }\end{array}$ & $\begin{array}{l}\text { Not reflecting } \\
\text { the rationale }\end{array}$ & $\begin{array}{l}\text { Reflecting less than half } \\
\text { of the rationale }\end{array}$ & $\begin{array}{l}\text { Reflecting more than half } \\
\text { of the rationale }\end{array}$ \\
\hline f) & $\begin{array}{l}\text { Performance measures address } \\
\text { any negative effects. }\end{array}$ & $\begin{array}{l}\text { Not addressing } \\
\text { negative effects }\end{array}$ & $\begin{array}{l}\text { Reflecting less than half } \\
\text { of the negative effects }\end{array}$ & $\begin{array}{l}\text { Reflecting more than half } \\
\text { of the negative effects }\end{array}$ \\
\hline g) & $\begin{array}{l}\text { Targets are reasonable for } 10- \\
\text { year estimates. }\end{array}$ & Not provided & $\begin{array}{l}\text { One target is provided } \\
\text { for all } 10 \text { years. }\end{array}$ & $\begin{array}{l}\text { Providing targets for } \\
\text { different periods over } 10 \\
\text { years and showing } \\
\text { improvement of the targets }\end{array}$ \\
\hline
\end{tabular}


Table 3: Criteria for evaluation of territorial authorities' water supply disclosures based on Intervention 2: the OAG's (2010a) criticism

\begin{tabular}{|c|c|c|c|c|}
\hline \multirow{2}{*}{\multicolumn{2}{|c|}{ Item }} & \multicolumn{3}{|c|}{ Criteria for Scoring } \\
\hline & & 0 & 1 & 2 \\
\hline h) & $\begin{array}{l}\text { Water supply is } \\
\text { aggregated with } \\
\text { similar activities }\end{array}$ & Not aggregated & $\begin{array}{l}\text { Aggregated inappropriately, } \\
\text { eg. with roading, solid waste, } \\
\text { waste management, \& waste }\end{array}$ & $\begin{array}{l}\text { Aggregate with similar } \\
\text { services, eg. waste water, } \\
\text { storm water }\end{array}$ \\
\hline
\end{tabular}


Table 4 : Criteria for evaluation of territorial authorities' water supply disclosures based on Intervention 3: better practice examples (OAG, 2010b)

\begin{tabular}{|c|c|c|c|c|}
\hline \multirow{2}{*}{\multicolumn{2}{|c|}{ Items }} & \multicolumn{3}{|c|}{ Criteria for Scoring } \\
\hline & & $\mathbf{0}$ & 1 & 2 \\
\hline i) & $\begin{array}{l}\text { Water quality } \\
\text { responsiveness: }\end{array}$ & $\begin{array}{l}\text { No performance } \\
\text { measures provided }\end{array}$ & $\begin{array}{l}\text { one performance } \\
\text { measure provided }\end{array}$ & $\begin{array}{l}\text { More than one } \\
\text { performance measure } \\
\text { provided }\end{array}$ \\
\hline j) & Quality of water supply & $\begin{array}{l}\text { No performance } \\
\text { measures provided }\end{array}$ & $\begin{array}{l}\text { one performance } \\
\text { measure provided }\end{array}$ & $\begin{array}{l}\text { More than one } \\
\text { performance measure } \\
\text { provided }\end{array}$ \\
\hline k) & $\begin{array}{l}\text { Local governments' } \\
\text { service responses to } \\
\text { incidents. }\end{array}$ & $\begin{array}{l}\text { No performance } \\
\text { measures provided }\end{array}$ & $\begin{array}{l}\text { one performance } \\
\text { measure provided }\end{array}$ & $\begin{array}{l}\text { More than one } \\
\text { performance measure } \\
\text { provided }\end{array}$ \\
\hline 1) & $\begin{array}{l}\text { Water interruption or } \\
\text { availability }\end{array}$ & $\begin{array}{l}\text { No performance } \\
\text { measures provided }\end{array}$ & $\begin{array}{l}\text { one performance } \\
\text { measure provided }\end{array}$ & $\begin{array}{l}\text { More than one } \\
\text { performance measure } \\
\text { provided }\end{array}$ \\
\hline m) & Water flow and pressures & $\begin{array}{l}\text { No performance } \\
\text { measures provided }\end{array}$ & $\begin{array}{l}\text { one performance } \\
\text { measure provided }\end{array}$ & $\begin{array}{l}\text { More than one } \\
\text { performance measure } \\
\text { provided }\end{array}$ \\
\hline n) & Water conservation: & $\begin{array}{l}\text { No performance } \\
\text { measures provided }\end{array}$ & $\begin{array}{l}\text { one performance } \\
\text { measure provided }\end{array}$ & $\begin{array}{l}\text { More than one } \\
\text { performance measure } \\
\text { provided }\end{array}$ \\
\hline o) & Firefighting: & $\begin{array}{l}\text { No performance } \\
\text { measures provided }\end{array}$ & $\begin{array}{l}\text { one performance } \\
\text { measure provided }\end{array}$ & $\begin{array}{l}\text { More than one } \\
\text { performance measure } \\
\text { provided }\end{array}$ \\
\hline
\end{tabular}


Table 5: Wilcoxon Signed Ranks Test for the index items

\begin{tabular}{|c|c|c|c|c|c|c|c|c|c|c|}
\hline \multirow{2}{*}{\multicolumn{2}{|c|}{ Items }} & \multicolumn{3}{|c|}{$2006<2009$} & \multicolumn{3}{|c|}{$2009<2012$} & \multicolumn{3}{|c|}{$2006<2012$} \\
\hline & & $\mathbf{Z}$ & Sig. & $\begin{array}{l}\text { Expected } \\
\text { sign }\end{array}$ & $\mathbf{Z}$ & Sig. & $\begin{array}{c}\text { Expected } \\
\text { sign }\end{array}$ & $\mathbf{Z}$ & Sig. & $\begin{array}{c}\text { Expected } \\
\text { sign }\end{array}$ \\
\hline \multicolumn{11}{|c|}{ Based on Intervention 1: OAG's (2007) criticism } \\
\hline a) & $\begin{array}{l}\text { Rationale for council's } \\
\text { activity }\end{array}$ & 1.921 & .055 & + & $\begin{array}{c}- \\
1.193\end{array}$ & .233 & + & .321 & .748 & + \\
\hline b) & Levels of service & .342 & .732 & + & 1.945 & .052 & + & -1.179 & .238 & + \\
\hline c) & $\begin{array}{l}\text { Levels of service reflect } \\
\text { rationale of the activity. }\end{array}$ & .000 & 1.000 & + & .000 & $\begin{array}{c}1.00 \\
0\end{array}$ & + & -1.000 & .317 & + \\
\hline d) & $\begin{array}{l}\text { Negative effects of } \\
\text { water supply services }\end{array}$ & 2.298 & $.022 *$ & + & .561 & .575 & + & 2.935 & $\begin{array}{c}.003 * \\
*\end{array}$ & + \\
\hline e) & $\begin{array}{l}\text { Performance measures } \\
\text { reflect the rationale. }\end{array}$ & 1.134 & .257 & + & 1.000 & .317 & + & 1.633 & .102 & + \\
\hline f) & $\begin{array}{l}\text { Performance measures } \\
\text { address any negative } \\
\text { effects. }\end{array}$ & .241 & .810 & + & -.608 & .543 & + & 1.052 & .293 & + \\
\hline g) & $\begin{array}{l}\text { Targets are reasonable } \\
\text { for } 10 \text { year estimates }\end{array}$ & 4.616 & $\begin{array}{c}.000 * \\
*\end{array}$ & + & .500 & 617 & + & 5.184 & $\begin{array}{c}.000 * \\
*\end{array}$ & + \\
\hline \multicolumn{11}{|c|}{ Based on Intervention 2: the OAG's (2010a) criticism } \\
\hline h) & $\begin{array}{l}\text { Aggregation of water } \\
\text { supply }\end{array}$ & 1.139 & .255 & + & 3.802 & $\begin{array}{l}.000 \\
* *\end{array}$ & + & -2.928 & $\begin{array}{c}.003 * \\
*\end{array}$ & + \\
\hline \multicolumn{11}{|c|}{ Based on Intervention 3: Better Practice Examples (OAG 2010b) } \\
\hline i) & $\begin{array}{l}\text { Water quality } \\
\text { responsiveness: }\end{array}$ & .000 & 1.000 & + & -.577 & .564 & + & -.333 & .739 & + \\
\hline j) & Quality of water supply & .000 & 1.000 & + & -.426 & 670 & + & -.332 & .740 & + \\
\hline k) & $\begin{array}{l}\text { Local governments' } \\
\text { service responses to } \\
\text { incidents. }\end{array}$ & 1.106 & .269 & + & -.999 & .318 & + & .354 & .723 & + \\
\hline 1) & $\begin{array}{l}\text { Water interruption or } \\
\text { availability }\end{array}$ & .862 & .389 & + & .447 & .655 & + & 1.155 & .248 & + \\
\hline $\mathrm{m})$ & $\begin{array}{l}\text { Water flow and } \\
\text { pressures }\end{array}$ & -1.151 & .250 & + & 2.285 & $\begin{array}{l}.022 \\
*\end{array}$ & + & -2.502 & $.012 *$ & + \\
\hline n) & Water conservation: & 1.826 & .068 & + & 2.162 & $\begin{array}{c}.031 \\
*\end{array}$ & + & .315 & .753 & + \\
\hline & Firefighting: & .908 & .364 & + & 1.890 & .059 & + & -.842 & .400 & + \\
\hline
\end{tabular}

** Significant at $\mathrm{p}<0.01$, two-tailed

* Significant at $\mathrm{p}<0.05$, two-tailed 
Table 6: Paired Samples $t$-test of Index 1 and Index 2

\begin{tabular}{|c|c|c|c|c|c|c|c|c|c|}
\hline \multirow[t]{2}{*}{ Index } & \multicolumn{3}{|c|}{$2006<2009$} & \multicolumn{3}{|c|}{$2009<2012$} & \multicolumn{2}{|c|}{$2006<2012$} & \multirow[b]{2}{*}{$\begin{array}{l}\text { Expected } \\
\text { sign }\end{array}$} \\
\hline & Mean & Sig. & $\begin{array}{l}\text { Expected } \\
\text { sign }\end{array}$ & Mean & Sig. & $\begin{array}{l}\text { Expected } \\
\text { sign }\end{array}$ & Mean & Sig. & \\
\hline $\begin{array}{l}\text { Index } 1 \text { score based on } \\
\text { OAG's (2007) criticism }\end{array}$ & 1.727 & $.001 * *$ & + & -.606 & .207 & + & 1.121 & .063 & + \\
\hline $\begin{array}{l}\text { Index } 2 \text { score based on } \\
\text { OAG's (2010b) Better } \\
\text { Practice }\end{array}$ & .242 & .418 & + & -.621 & $.002 * *$ & + & -.379 & .220 & + \\
\hline
\end{tabular}

